DOMINIK ZAMIATAŁA* - WARSZAWA

\title{
KONFERENCJA WYŻSZYCH PRZELOŻONYCH ZAKONÓW MĘSKICH W POLSCE I KONSULTA ZAKONNA PRL
}

Wyzwolenie ziem polskich spod okupacji hitlerowskiej w 1945 r. przez wojska armii czerwonej, pomogło komunistom podległym całkowicie Moskwie w przejęciu władzy i doprowadziło do zmiany warunków społecznych, ekonomicznych i politycznych w Polsce. Miało to też wpływ na relacje państwo-Kościół. Prymas A. Hlond zdawał sobie sprawę z niebezpieczeństwa jakie niesie nowa lansowana przez nowe komunistyczne władze materialistyczna ideologia. Był przekonany,żekomuniści prędzej czy później podejmąwalkęzKościołemi w pierwszej kolejności uderzą w zakony w Polsce. Zachęcał więc zakony i zgromadzenia zakonne do jednoczenia wysiłków i podejmowania wspólnych działań. Przestrzegał też zakonników przed penetracją policji politycznej.

Rady prymasa, rozwijająca się sytuacja wokół Kościoła w Polsce oraz konieczność przyjęcia wspólnego stanowiska wobec władz państwowych, które zaczęły stwarzać trudności i nękać zakony na wielu odcinakach dotychczasowej ich działalności, spowodowały, że zakony męskie zaczęły dostrzegać potrzebę wspólnych konsultacji dotyczących nowych kierunków życia zakonnego i podejmowania działań w celu jednolitej obrony ${ }^{1}$. Chciały razem odnaleźć się w nowej politycznej rzeczywistości. Przyjęcie jednolitej postawy dawało zakonom dobre wyniki i przed władzami pokazywało siłę zakonów. Były też zainteresowane wspólnym planowaniem prac pod kierunkiem Episkopatu, który stawiał jasno kwestię współpracy zakonów w działaniach duszpasterskich. Pierwsze wspólne spotkanie prowincjałów z udziałem prymasa A. Hlonda odbyło się 5 grudnia 1945 r. na Jasnej Górze. Prowincjałowie spotkali się wtedy w celu przedyskutowania roli zakonów w nowej powojennej rzeczywistości i nowych zadań jakie przed nimi stanę-

* Dominik Zamiatała CMF - dr historii Kościoła, adiunkt w Instytucie Politologii Uniwersytetu Kardynała Stefana Wyszyńskiego w Warszawia.

${ }^{1}$ AKWPZM, T. Sprawy różne, Pismo Konsulty Wyższych Przełożonych Zakonów Męskich w Polsce do ks. Prałata Agostino Casaroli Podsekretarza Stanu do Spraw Nadzwyczajnych z 6 III 1967 r., b. p. 
ły². Kilka dni później z inicjatywy abp. A. Sapiehy spotkali się ponownie w Krakowie w celu omówienia sytuacji życia zakonnego po wojnie i sposobom jego odrodzenia mimo strat osobowych i zniszczeń materialnych, jakie zakony doświadczyły w czasie okupacji. W spotkaniu wzięło udział 20 prowincjałów ${ }^{3}$. W grudniu 1948 r. na zjeździe zorganizowanym przez kard. A. Sapiehę po śmierci kard. A. Hlonda, wśród wyższych przełożonych zrodził się pomysł zorganizowania porozumienia wyższych przełożonych ${ }^{4}$. Pomysł ten poparł ordynariusz krakowski. Na prośbę prowincjałów, sprawami zorganizowania takiej instytucji zajął się prowincjał pijarów o. Bonawentura Kadeja. Prowincjałowie poprosili kard. A. Sapiehę o wyznaczenie któregoś z biskupów na protektora zakonów w Episkopacie. Kardynał Sapieha wskazał na bp. M. Klepacza. Ten jednak odmówił. Ostatecznie funkcję tę objął bp Tadeusz Zakrzewski z Płocka, który w trakcie spotkania z przedstawicielami prowincjałów szczerze wyznał, że nie zna potrzeb zakonnych, a przyjął tę funkcję, ponieważ inni ordynariusze nie chcieli jej przyjąć. Prowincjałowie po rozmowach z bp. M. Klepaczem i bp. T. Zakrzewskim, uświadomili sobie, że jedynie mogą liczyć na metropolitę krakowskiego i prymasa. Po śmierci kardynała A. Hlonda jego następca S. Wyszyński od początku urzędowania odnosił się do spraw zakonnych ze zrozumieniem. Nowy prymas -jak zauważyli prowincjałowie- nie wyróżniał żadnego zakonu, a jedynie cenił poszczególnych zakonników ${ }^{5}$.

Pod przewodnictwem prymasa kard. Augusta Hlonda odbyło się kilka spotkań wyższych przełożonych zakonnych. Były one głównie poświęcone sytuacji Kościoła i zakonów w Polsce oraz sprawom duszpasterstwa w nowej rzeczywistości polskiej i udziału w nim zakonów męskich zwłaszcza na Ziemiach Zachodnich i Północnych. W 1948 r. na spotkaniu prowincjałów w klasztorze jezuitów w Krakowie dyskutowano nad środkami obrony i zabezpieczenia na przyszłość zakonów, gdyż wielu z nich zdawało sobie sprawę, że komunistyczne rządy prędzej czy później zabiorą zakonom szpitale, szkoły, majątki. Podkreślano potrzebę jednolitego postępowania ${ }^{6}$. Na tym spotkaniu powołano do istnienia Porozumienie Wyższych Przełożonych Zakonów i Zgromadzeń Męskich w Polsce i wybrano skład prezydium. W skład prezydium weszli o. B. Przybylski OP, ks. W. Krupa SJ (Kraków), ks. J. Ślusarczyk SDB i ks. B. Kadeja SchP jako sekretarz. Ustalono, że na zjazdy będą przyjeżdżali tylko przełożeni wyżsi. Od 1951 r. spotkania pro-

${ }^{2}$ G. Bartoszewski, Postuga kardynała Augusta Hlonda jako Prymasa Polski zatroskanego o życie zakonne [mps w posiadaniu autora]; F. Berlik, Moje wspomnienie założyciela, w: Kardynat August Hlond Prymas Polski. Wspótcześni wspominaja Stugę Bożego kard. Augusta Hlonda, opr. W. Necel, Poznań 2006, s. 94.

${ }^{3}$ IPN, sygn. 01283/1057, V14-51P -1/-1, Zeznanie Edwarda Bulandy w sprawie organizacji i działalności Konferencji Prowincjałów Zakonnych i Prezydium z Sekretariatem, k. 4.

${ }^{4}$ Tamże, k. 2.

${ }^{5}$ Tamże, k. 11.

${ }^{6}$ Tamże, k.4.

${ }^{7}$ Prowincjał pijarów ks. Bonawentura Kadeja w latach 1949-1957 był sekretarzem Konferencji Wyższych Przełożonych Zakonów męskich; IPN, sygn. 01283/1057, V14-51P -1/-2, Streszczanie sprawy przeciwko Bulandzie Edwardowi, prowincjałowi zak. Jezuitów i tow. tow., k. 52-56. 
wincjałów zaczęły się odbywać dwa razy w roku i nazywano je Konferencjami Wyższych Przełożonych. W styczniu 1949 r. na kolejnym zebranie wyższych przełożonych zadecydowano, że kolejne zjazdy będą zwoływane przez sekretarza i będą nazywane - „Dni Skupienia Wyższych Przełożonych”. Określono również cel wspólnych spotkań. Zasadniczym celem zjazdów prowincjałów miała być wzajemna pomoc, porady sprawowaniu urzędu prowincjała w nowej rzeczywistości powojennej, koordynowanie pracy zakonów i zgromadzeń zakonnych na terenie kraju oraz wspólne rozwiązywanie wewnętrznych i zewnętrznych problemów ${ }^{8}$. Od 1949 r. zebrania prowincjałów zajmowały się przede wszystkim problemem współpracy duszpasterskiej i życia zakonnego w nowej sytuacji społeczno politycznej oraz wspólnej obrony wobec narastających coraz większych trudności ze strony komunistycznych władz. Na przykład we wrześniu 1949 r. spotkanie prowincjałów było poświęcone głównie wydanemu 5 VIII 1949 r. przez władze państwowe nowemu prawu o stowarzyszeniach, które wywołało spore zaniepokojenie prowincjałów. Na zebraniu 26 IV 1952 r. w Gnieźnie z udziałem Prymasa S. Wyszyńskiego omawiano bieżące trudności życia zakonnego i zarzuty stawiane zakonnikom przez komunistów9 ${ }^{9}$ Zakony coraz bardziej doświadczające trudności ze strony władz państwowych na wielu odcinakach działalności, zaczęły nawiązywać też ściślejszą współpracę z episkopatem.

Współpraca wyższych przełożonych zakonów męskich nabrała większego rozmachu po 1956 r. W styczniu 1957 r. kardynał S. Wyszyński oparciu o wydany rok wcześniej przez Kongregację do Spraw Zakonów dekret „Salutaris” powołał do życia Konsultę Wyższych Przełożonych Zakonów Męskich w Polsce przy Sekretariacie Prymasa Polski ${ }^{10}$. Konsulta składała się z pięciu osób i współpracowała z Episkopatem. Każdy członek Konsulty był także członkiem jednej z komisji Episkopatu, np. prowincjał pijarów był członkiem komisji do spraw dobroczynnych. Według ramowego statutu celem jej było: „1)Zapoznawanie się z orzeczeniami Stolicy Św., zwłaszcza dotyczącymi życia zakonnego. 2) Omawianie problemów życia zakonnego, zadań stojących przed Zakonami w obecnych czasach i warunkach oraz uzgadnianie stanowiska zakonów w sprawach wspólnych. 3) Uświadamianie społeczeństwa o zadaniach i wartościach życia zakonnego a w razie potrzeby wspólnej akcji obronnej. 4) Wzajemna wymiana doświadczeń

${ }^{8}$ Ustalono, że na zjazdy zwoływane przez sekretarza, będą przyjeżdżali tylko przełożeni wyżsi. Zjazdy nosiły nazwę „Dni Skupienia Wyższych Przełożonych”. W 1954 r. prezydium przekształciło się w Referat Spraw Zakonnych przy Przewodniczącym Konferencji Episkopatu Polski. Sekretarz odtąd będzie Referentem Spraw Zakonnych. Tamże.

${ }^{9}$ Stefan kardynat Wyszyński. Pro memoria. Zapiski z lat 1948-1949 i 1952-1952, Warszawa 2007, s. 148.

${ }^{10}$ Współpracę zakonów na terenie jednego kraju lub kilku państw według grup regionalnych, narodowych w kwestii np. apostolstwa, wychowania, charytatywnej zapoczątkował Ogólny Kongres zakonów i zgromadzeń zakonnych w grudniu 1950 r. w Rzymie. Wzorem stała się powołana w 1959 r. Konfederacja Zakonów Ameryki Łacińskiej. Od tego czasu organizacje te działają w kilkudziesięciu państwach. W 1957 r. powstała ponadnarodowa organizacja - Unia Wyższych Przełożonych Generalnych (zakonów męskich). 
między poszczególnymi Zakonami. 5) Opracowywanie i podejmowanie wspólnych postulatów czy akcji wobec Władz Kościelnych i Państwowych”. Kierowała się ona statutem Konferencji Wyższych Przełożonych Zakonów Męskich w Polsce, zatwierdzonym przez Prymasa Polski (15 IV 1958 r.) na okres trzech lat ${ }^{11}$. Na mocy tego statutu, prowincjałowie zostali zobowiązani, aby w szczególnych wypadkach i ze względu na wspólne dobro zakonów, wprowadzać w życie w swoich wspólnotach zakonnych, powzięte przez Konferencję postanowienia. Konferencja Wyższych Przełożonych Zakonów Męskich w Polsce (KWPZM) nie otrzymała kościelnej osobowości prawnej i działała tylko jako wzajemne porozumienie wyższych przełożonych. Konferencja nie współpracowała bezpośrednio z Konferencją Episkopatu. Przedstawiciel Konferencji Wyższych Przełożonych nie brał udziału w Konferencjach plenarnych biskupów ani w Komisji Głównej Episkopatu. Nie udało się zakonom założyć w Polsce międzyzakonnych ośrodków formacji zakonnej czy wyższej kultury religijnej. Konferencja miała słabą łączność z Unią Przełożonych generalnych. Nawiązała jedynie na początku lat 70., kontakty z niektórymi sekretariatami innych krajowych Konferencji Wyższych Przełożonych. Najważniejszą rolę pełnił w niej praktycznie referent, który był pracownikiem Wydziału Spraw Zakonnych przy Sekretariacie Prymasa. Od 1967 r. istniała specjalna Komisja Episkopatu dla Spraw Zakonnych, do której należeli biskupi i wyżsi przełożeni zakonów męskich i żeńskich ${ }^{12}$. Poprzez tę komisję zakony przedkładały problemy życia zakonnego. Sekretariat Episkopatu zaś załatwiał wszystkie ogólne sprawy zakonne w czasie rozmów przedstawicieli Episkopatu z polskimi władzami. Sekretariat udzielał zakonom porad prawnych w sprawach konfliktowych z różnymi instancjami państwowymi oraz informował zakony o wszystkich zaobserwowanych zmianach ${ }^{13}$. Wynikało to z jednolitego działania Kościoła w Polsce we wszystkich sprawach kościelnych na płaszczyźnie państwo-Kościół.

Kościelną osobowość prawną z zatwierdzonym nowym statutem Konferencja WPZM otrzymała dopiero w listopadzie 1963 r. dekretem Kongregacji Zako-

${ }^{11}$ AKWPZM, t. sprawy różne, Ramowy statut Konferencji Wyższych Przełożonych Zakonów Męskich w Polsce z 15 IV 1958 r., b. p.; AAN, UdSW, sygn. 133/53, Ramowy statut Konferencji Wyższych Przełożonych Zakonów Męskich w Polsce z 15 IV 1958 r., k. 1-3.

${ }^{12}$ W Komisji do Spraw Zakonnych Episkopatu zasiadało 6 biskupów ( w tym 2 zakonników) 5 członków Konsulty Zakonów Męskich i 3 przedstawicielki Konsulty Zakonów Żeńskich. W latach 70. przewodniczącym tej komisji był bp B. Dąbrowski. W drugiej połowie lat 70. Konsulta wysunęła postulat, by istniejąca Komisja Episkopatu d/s Zakonnych złożona była wyłącznie z przedstawicieli Episkopatu i Wyższych Przełożonych, przy czym liczba jednych i drugich przedstawicieli powinna być równa. Do Komisji tej z urzędu powinien wejść Przewodniczący i Sekretarz Konferencji, inni zaś członkowie zostaną przedstawieni przez Konferencję Wyższych Przełożonych do zatwierdzenia. W skład tej Komisji wejdą również Przedstawicielki Konferencji Wyższych Przełożonych Zakonów Żeńskich. Propozycja Konsulty została przyjęta przez Konferencję Episkopatu. AKWPZM, t. Konferencja Wyższych Przełożonych, Sprawozdanie z działalności Konferencji Wyższych Przełożonych Męskich Instytutów Zakonnych w Polsce, b.p.

${ }^{13}$ AKWPZM, T. Konferencja Wyższych Przełożonych, Konferencja Wyższych Przełożonych Zakonów Męskich w Polsce /1964-1968/, b. p. 
nów ${ }^{14}$. Konferencja uzyskała całkowitą autonomię wewnętrzną, jednak ze względu na autorytet Prymasa S. Wyszyńskiego, aż do końca lat 70., działała w oparciu o zatwierdzony przez niego statut $\mathrm{z}$ marca 1963 roku ${ }^{15}$. Z powodu zewnętrznych warunków politycznych, Prymas zarezerwował sobie prawo mianowania 5 członków Konsulty i jej sekretarza spośród przedstawionych mu przez zebranie plenarne Konferencji 10 kandydatów $^{16}$. Oni tworzyli Konsultę na okres trzech lat.

Konferencja Wyższych Przełożonych zakonnych podobnie jak w okresie stalinowskim, starała się zachować jednolitą postawę wobec różnych dyskrymina-

${ }^{14}$ Nowy statut zasadniczo zawierał treść statutu zatwierdzonego przez Prymasa Polski (25 III 1963 r. Ten drugi statutu Konferencji WPZM został uchwalony na zebraniu plenarnym 08 III 1963 roku Określał on nazwę Konferencji, charakter prawny, cel, sposób pracy. Konferencja nadal nie posiadała osobowości prawnej i pełnej samodzielności w działaniu, dlatego w dalszym ciągu dokonywane wybory zatwierdzane były przez Księdza Prymasa. Konferencja miała się starać o „Pogłębienie współżycia aktualnego z Kościołem, żywy udział w jego pracach i dziełach, zapoznawanie się z orzeczeniami i wskazaniami Stolicy św., zwłaszcza dotyczący mi życia zakonnego. Omawianie problemów życia zakonnego, zadań stojących przed Zakonami w obecnych czasach i warunkach oraz uzgadnianie stanowisk Zakonów w sprawach wspólnych. Wzajemna wymiana doświadczeń między poszczególnymi Zakonami. Uświadamianie społeczeństwa o zadaniach i wartościach życia zakonnego. Opracowywanie i podejmowanie wspólnych prac i przedstawianie postulatów Władzom Kościelnym. Uzgadnianie w duchu solidarności chrześcijańskiej i aktualnych potrzeb wspólnych wystąpień i działalności w ramach życia publiczno-prawnego dla obrony interesów w życia zakonnego.” AKWPZM, t. sprawy różne, Statut Konferencji Wyższych Przełożonych Zakonów Męskich w Polsce z 25 III 1963 r., b. p.

${ }^{15}$ Po Soborze Watykańskim II Kongregacja Zakonów zatwierdzała nowy odnowiony statut (25 I 1975 r.) na okres pięciu lat. AKWPZM, t. sprawy różne, statut Konferencji Wyższych Przełożonych Zakonów Męskich w Polsce z 1975 r., b. p.; W roku 1980 statut został ponownie potwierdzony na nowe pięciolecie. Po drobnych poprawkach 17 XII 1984 r. statut został zatwierdzony na kolejne dziesięć lat. AKWPZM, T. Sprawy różne, Dekret Św. Kongregacji Dla Zakonów i Instytutów Świeckich, Rzym 28 IV 1980 r., b. p.

${ }^{16}$ Wyznaczał pięciu z przedstawionych przez Konferencję Przełożonych kandydatów. Oni wybierali spośród siebie przewodniczącego, którego zatwierdzał Prymas. Przewodniczącymi konferencji byli: o. Stanisław Wawryn SJ (1957-1960), o. Feliks Zapłata SVD (1960-1963), o. Bernard Przybylski OP (1963-1966), o. Kazimierz Hołda CSSR (1966-1972), o. Stanisław Podgórski CSSR (1972-1981), o. Pacyfik Dydycz OFMCap. (1981-1982), o. Walenty Potworowski OP (1982-1984), o. Mariusz Paczóski OFMConv. (1984-1989), o. Błażej Kruszyłowicz OFMConv. (1989-1990). Obowiązki sekretarzy pełnili: o. Bonawentura Kadeja SCH.P. (1949-1956), ks. Alojzy Żuchowski SAC (1957-1977), ks. Wacław Rusinek SDB od 1977. Przez wiele lat praktyka odnośnie wyboru konsulty wyższych przełożonych zakonnych była taka, z Konferencji Wyższych Przełożonych Zakonnych przedstawiała Prymasowi 10 kandydatów wybranych na konferencji przez głosowanie, który z tej liczby wyznaczał 5 i oni tworzyli Konsultę na okres trzech lat. Z reguły wyznaczał pierwszych pięciu z przedstawionej mu listy. W maju 1975 r. zmieniono zasadę wyboru członków Konsulty i zgodnie z nowym statutem wyboru dokonywała wyłącznie Konferencja Wyższych Przełożonych zakonnych. Konsulta zbierała się, co najmniej, co dwa miesiące. AKWPZM, T. Sprawy różne, Sprawozdanie z działalności Zakonów męskich z 1959 r., b. p.; AKWPZM, T. Sprawy różne, Pismo sekretarza Konsulty KWPZM do Prymasa S. Wyszyńskiego z 27 VI 1972 r. b.p.; AKWPZM, T. Sprawy różne, Pismo sekretarza Konsulty KWPZM do Prymasa S. Wyszyńskiego z 11 IV 1972 r. b. p; tamże, Wybory Konsulty z dnia 17 V 1978 r., b. p.; AKWPZM, T. Sprawy różne, Wybory Konsulty z dnia 14 V 1975 r. Warszawa, ul. Freta 10/, b. p. 
cyjnych działań władz komunistycznych wobec zakonów. Wynikało to z jednolitego działania Kościoła w Polsce we wszystkich sprawach kościelnych na płaszczyźnie państwo - Kościół. Jej zebrania przygotowywane przez Konsultę i referenta i uzgodnione z Prymasem, odbywały regularnie ${ }^{17}$. Ogólnym zebraniom konferencji oraz spotkaniom Konsulty przewodniczył jej przewodniczący, który był także rzecznikiem spraw ogólnozakonnych i reprezentował zakony u Prymasa, Episkopatu i Władz Państwowych. Utrzymywał on stały kontakt z Prymasem, przedstawiał mu programy Konferencji i sprawy zakonne i duszpasterskie zakonów. Zapraszał członków Episkopatu na obrady Konferencji w sprawach odnoszących się do relacji biskupi-zakony. Każdy Konsultor, który ustępował ze stanowiska wyższego przełożonego, składał również na ręce Ks. Prymasa rezygnację z funkcji Konsultorskiej. Konsulta opracowywała program Konferencji i ustala ich terminy i miejsca obrad. Konsulta zbierała się zależnie od powstających potrzeb nie rzadziej jednak niż trzy razy do roku ${ }^{18}$. Sekretariat Konsulty był związany z Wydziałem Spraw Zakonnych ${ }^{19}$. Na przykład od 12 V 1969 r. do 10 IV 1972 r. w skład Konsulty wchodzili prowincjałowie: O. Kazimierz Hołada redemptorysta, ks. Józef Król salezjanin, ks. Stanisław Nawrocki jezuita, ks. Andrzej Wróbel kanonik regularny i O. Jerzy Tomziński generał Paulinów ${ }^{20}$. W tych trzech latach Konsulta odbyła 12 posiedzeń. Na tych posiedzeniach rozpatrywano ówczesne zagrożenia życia zakonnego oraz obawy o poziom życia zakonnego w wyniku wprowadzanej posoborowej odnowy życia zakonnego. Wielu ówczesnych prowincjałów miało w tym względzie potężne obawy. Dwa razy do roku przewodniczący Konsulty miał audiencję u Prymasa informując go o jej pracach. Z episkopatem współpraca ograniczała się tylko do działań w ramach Komisji Spraw Zakonnych przy Konferencji Episkopatu Polski, gdzie uzgodniono m.in. takie sprawy jak: jurysdykcja dla wyższych przełożonych i ich zastępców, sprawa zaliczeń egzaminów zakonnych do święceń i jurysdykcji, oraz sprawa wykonania ustawy

${ }^{17}$ Konferencja utrzymywała stałą łączność z Księdzem Prymasem poprzez ks. Bronisława Dąbrowskiego. Pomagał Konferencji najpierw jako Dyrektor Wydziału Spraw Zakonnych, a później jako biskup. Pełniąc obowiązki Sekretarza Generalnego Konferencji Episkopatu Polski, ułatwiał współpracę Konferencji WPZM z Konferencją Episkopatu. O. Joachim Bar OFMConv., Konferencje Wyższych Przełożonych Zakonów w Polsce, w: Prawo Kanoniczne 1980 nr 3-4, s. 99-116

${ }^{18}$ AKWPZM, T. Sprawy różne, Ramowy statut Konferencji Wyższych Przełożonych Zakonów Męskich w Polsce z 15 IV 1958 r., b. p.; AKWPZM, T. Konsulta, Sprawozdanie z działalności Konsulty w okresie kadencji: 12 V 1969 - 10 IV 1972, b. p.

${ }^{19}$ Przewodniczącymi konferencji byli: o. Stanisław Wawryn SJ (1957-1960, o. Feliks Zapłata SVD (1960-1963), o. Bernard Przybylski OP (1963-1966), o. Kazimierz Hołda CSSR (1966-1972), o. Stanisław Podgórski CSSR (1972-1981), o. Pacyfik Dydycz OFMCap. (1981-1982), o. Walenty Potworowski OP (1982-1984), o. Mariusz Paczóski OFMConv. (1984-1989), o. Błażej Kruszyłowicz OFMConv. (1989-1990). Obowiązki sekretarzy pełnili: o. Bonawentura Kadeja SCH.P. (1949-1956), ks. Alojzy Żuchowski SAC (1957-1977), ks. Wacław Rusinek SDB od 1977. AKWPZM, T. sprawy różne, Sprawozdanie z działalności Zakonów męskich z 1959 r., b. p.; AAN, UdSW, sygn. 138/29, Materiały i informacje. Zakony Kościoła rzymskokatolickiego w Polsce, grudzień 1977, k. 5.

${ }^{20}$ AKWPZM, t. Konsulta, Sprawozdanie z działalności Konsulty w okresie kadencji: 12 V 1969 -10 IV 1972, b.p. 
sejmowej z 23 VI 1971 r. o przejściu na osoby prawne Kościoła własności niektórych nieruchomości na Ziemiach Zachodnich i Północnych ${ }^{21}$.

Zakres prac Konsulty poszerzały powoływane w zależności od potrzeb KWPZM różnego rodzaju Komisje. Pod koniec lat 50. działały następujące Komisje: Życia i karności zakonnej, Wychowania i studiów, Apostolstwa i duszpasterstwa, Powołań zakonnych i kapłańskich, Dzieł zakonnych. Ich zadaniem było $\mathrm{m}$. in. organizowanie spotkań zakonników w ramach swej specjalności, przygotowywanie materiałów na konferencje plenarne $\mathrm{K}^{22}$. W drugiej połowie lat 70 . W ramach Konsulty pracowało 9 komisji: Życia i Karności Zakonnej, Powołań Zakonnych i Kapłańskich, Wychowania i Studiów, Apostolstwa, Duszpasterstwa Specjalistycznego, Dzieł Miłosierdzia, Liturgiczna, Misji i Polonii zagranicznej oraz Prawna.

Do komisji działających przy konsulcie prowincjałowie na ogół zgłaszali się sami. Większość ograniczała się tylko do pracy w jednej komisji, a tylko nieliczni do dwóch i więcej23. Komisje podejmowały prace wskazane przez zebranie plenarne. Z inicjatywy Konsulty w styczniu 1963 r. odbyło się dwudniowe spotkanie dla rekolekcjonistów zakonnych i duszpasterskich referentów zakonnych. ${ }^{24}$ W styczniu 1964 r. odbył się dwutygodniowy w Gostyniu w klasztorze filipinów miedzyzakonny kurs dla początkujących rekolekcjonistów i misjonarzy ludowych. Prowadził je Prowincjał filipinów ks. Kokociński. ${ }^{25}$ Komisja Powołań przy

${ }^{21}$ AKWPZM, T. Konsulta, Sprawozdanie z działalności Konsulty w okresie kadencji: $12 \mathrm{~V}$ 1969 - 10 IV 1972, b.p.

${ }^{22}$ AKWPZM, T. Sprawy różne, Sprawozdanie z działalności Zakonów męskich z 1959 r., b.p.; W 1972 r. przy Konferencji Wyższych Przełożonych Zakonów Męskich działały następujące Komisje: Komisja Życia i Karności Zakonnej, Komisja Wychowania i Studiów, Komisja Apostolstwa (a) Misje i rekolekcje parafialne, b) Pomoc dla ojców duchownych i spowiedników, c) Formacja kaznodziejska rekolekcyjno-misyjna młodych kapłanów zakonnych), 4. Komisja Duszpasterstwa Specjalistycznego, a) Referat ogólnoadministracyjny, b) Referat duszpasterstwa w rodzinach, o) Referat katechetyczny, d) Referat apostolstwa świeckich, e) Referat misyjny, f) Referat duszpasterstwa polonijnego, g) Referat duszpasterstwa turystyczno-wczasowego), 5.Komisja Powołań Zakonnych i Kapłańskich Rada Komisji a) Podkomisja Redakcji Materiałów b) Podkomisja informacji c) Podkomisja Liturgicznej Służby Ołtarza d) Podkomisja Jasnogórskiego Ośrodka Powołań), 6. Komisja Dzieł Zakonnych a) Podkomisja duszpasterstwa dobroczynności b) Podkomisja apostolstwa trzeźwości, c) Referat pomocy klasztorom sióstr klauzurowych d) Referat dzieł złoconych) 7. Komisja Liturgiczna. AKWPZM, T. Sprawy różne, Komisje Konferencji Wyższych Przełożonych Zakonów Męskich w 1972 r., b.p.

${ }^{23}$ AKWPZM, T. Sprawy różne, Zgłoszenia do Komisji, Warszawa dnia 15 V 1975 r., b.p.

${ }^{24} \mathrm{~W}$ jego ramach wygłoszono kilka referatów $\mathrm{m}$. in. na temat - Rola rekolekcji w urabianiu ascetycznym wiernych (O. Wójcik CSSR), Problemy wychowania w naukach rekolekcyjnych w VII Roku Wielkiej Nowenny (ks. Pruś SDB), właściwości rekolekcji wielkopostnych (ks. Gorzkowski TJ), rekolekcje okolicznościowe (ks. Kosiński SDB), rekolekcje stanowe (ks. Cieślak OMI), rekolekcje dla młodzieży (ks. Ryłko), Peregrynacja - co daje - możliwości - niebezpieczeństwa - zadania - wnioski (Bp. Stroba), AKWPZM, T. Sprawy różne, Sprawozdanie z działalności Zakonów męskich z 1964 r., b.p.

${ }^{25}$ AKWPZM, t. sprawy różne, Sprawozdanie z działalności Zakonów męskich z 1964 r., b.p. 
Konsulcie zaapelowała na początku lat 60 . do prowincjałów by zajęli się z obowiązku powołaniami. Także w latach 60 . Konsulta i konferencje prowincjałów zajęly się szczególnie kwestią braci zakonnych, gdyż stawał się to poważany problem życia zakonnego w Polsce. Komisja życia i Karności zakonnej zorganizowała w 1973 r. szkolenie dla braci zakonnych przebywających w junioracie. Wykłady trwały 6 tygodni i wzięło w nich udział 54 braci z różnych zakonów. Z jej inicjatywy w latach 70. działało Religijne Studium dla Braci zakonnych, by dać możliwość podniesienia wykształcenia religijnego braci zakonnych, gdyż nie wszystkie zakony mogły sobie pozwolić na takie studium ze względu na małą liczbę braci. Studium jest prowadzone każdego roku w styczniu i lutym. Program był rozłożony na trzy lata. Każdego roku brało w nim udział 30 braci. Bracia kończący studium zdawali egzaminy i otrzymywali dyplomy Prowadzone były tam wykłady z zakresu: teologia moralna, teologia dogmatyczna, mariologia życia wewnętrznego, Pismo św., liturgia, historia kościoła, Prawo Kanoniczne, śpiew kościelny, studium dokumentów soborowych, psychologia, zagadnienia współczesne, zagadnienia konserwacji zabytków, język polski, księgowość, zagadnienia trzeźwościowe, katechetyka ${ }^{26}$. Komisja powołań prowadziła szeroką akcję na rzecz powołań. Każdego roku (lata 70.) organizowano wiosenne i jesienne dni powołań, które gromadziły, co roku od 150 do 200 osób z różnych zakonów męskich i żeńskich, odpowiedzialnych za powołania. Komisja ta także przygotowywała materiały pomocnicze do kazań katechezy i nabożeństwa na Tydzień powołań. Sprawie powołań braci służyła specjalna wystawa „Bracia zakonni w Polsce” wystawiona w kilku dużych miastach w Polsce. Komisja Wychowani i Studiów zorganizowała spotkanie dla mistrzów nowicjatów i wychowawców młodzieży zakonnej. W 1975 r. na takim spotkaniu w którym wzięło udział 70 osób zastanawiano się nad najlepszymi sposobami poznania kandydatów zgłaszających się do życia zakonnego. Komisja Apostolstwa zorganizowała trzy dniowe spotkanie dla rekolekcjonistów i misjonarzy ludowych w Warszawie i Krakowie wzięło w nich udział 250 zakonników. Te spotkania odbywały się co roku i brało w nich udział ponad 200 osób. Takie spotkania były organizowane także w następnych latach. W 1975 r. ta komisja zorganizowała dwutygodniowy kurs dla młodych kaznodziejów zakonnych przygotowujących się do tej pracy. Kurs odbył się Gostyniu u filipinów i wzięło w nim udział 60 kapłanów ${ }^{27}$. Od 1977 r. były organizowane jednodniowe spotkania referentów d/s misji i rekolekcji. Poszukiwano na nich nowych form głoszenia kazań i możliwości ściślejszej współpracy grup misjonarzy z różnych rodzin zakonnych. Komisja Powołań Kapłańskich i Zakonnych zorganizowała w $1973 \mathrm{r}$. dwa spotkania referentów powołaniowych. Ta Komisja prowadziła w Niepokalanowie i na Jasnej Górze ośrodki powołaniowe. Przez te ośrodki jak obliczono co roku przewijało się od 70 do 80 tys. osób. Tam od maja do października przedstawiciele rodzin zakonnych mieli dyżury powołaniowe.

${ }^{26}$ AKWPZM, T. Konferencja Wyższych Przełożonych, Sprawozdanie z działalności Konferencji Wyższych Przełożonych Męskich Instytutów Zakonnych w Polsce, b.p.

${ }^{27}$ AKWPZM, T. Konferencja Wyższych Przełożonych, Sprawozdanie z działalności Konferencji Wyższych Przełożonych Zakonów Męskich w Polsce za okres 1 X 1972 - 1 XI 1973, b.p. 
Współpracowała z analogicznymi Komisjami Konferencji Episkopatu i Konferencji Żeńskich Instytutów Zakonnych. Komisja ta po uzgodnieniu z ordynariuszem miejsca prowadziła akcję powołaniową na terenie różnych diecezji. Do akcji powołaniowej wykorzystywano także pieszą pielgrzymką warszawską. Organizowała także wystawy powołaniowe, jak np. we Wrocławiu w 1975 r. wystawę poświęconą roli braci zakonnych. Komisja Dzieł Zakonnych zajmowała się organizowaniem pomocy materialnej klasztorom klauzurowym i rozwijała apostolstwo trzeźwości organizowała dwutygodniowe kursy dla kleryków i dni skupienia dla kapłanów chcących się zająć rekolekcjami o tematyce trzeźwościowej. W 1974 r. Komisja Dzieł Zakonnych zorganizowała w WSD zakonnych wykłady z zakresu alkohologii i organizowała kursy dla kapłanów prowadzących akcje trzeźwościowe wśród wiernych. Ta Komisja zajmowała się także akcją dobroczynną z ramienia Konferencji. Co roku w latach 70. Komisja wychowania i studiów organizowała dwudniowe spotkania dla mistrzów nowicjatów i wychowawców młodzieży zakonnej. Komisja Misji i Polonii zagranicznej współpracowała z Komisją Misyjną Episkopatu i Biurem Misyjnym. Miała za zadanie budzić zapał misyjny w kraju. Pod jej patronatem wydawano dwa czasopisma poświęcone tematyce misyjnej - „Serwis Misyjny” dwutygodnik zawierający informacje o pracy misyjnej różnych zakonów oraz „Misje” - kwartalnik. Organizowała każdego roku dni skupienia dla zakonnych animatorów misyjnych oraz spotkania dla misjonarzy przyjeżdżających do kraju na urlopy. W 1979 r. w czerwcu zorganizowała kilkudniowy kurs przygotowawczy dla 30 misjonarzy i misjonarek udających na mi$\mathrm{sje}^{28}$.

Na początku lat 60 . Konsulta nie przejawiała większej aktywności. Również

Komisje działające w jej ramach także nie przejawiały żadnej działalności. Dlatego by to zmienić ówczesny przewodniczący Konsulty O. Feliks Zapłata prowincjał werbistów, tworzył zespoły robocze w ramach komisji złożone $\mathrm{z}$ nieprowincjałów ${ }^{29}$. Po konsultacji z innymi prowincjałami w liście do Prymasa przedstawił pewne propozycje mające na celu większe uaktywnienie Konsulty w przyszłości. Pierwsza propozycja dotyczyła oddzielanie funkcji sekretarza Konsulty od Wydziału zakonnego przy sekretariacie Prymasa (ks. Alojzy Żuchowski był jednocześnie sekretarzem Konsulty i referentem Wydziału Zakonów w Sekretariacie Prymasa). Ponadto zaproponował konsekrowanie biskupa z grona zakonników, który zajmowałby się tylko zakonami z ramienia Prymasa.

Kosulta starał się, aby zakony koordynowały pracę duszpasterską i ewangelizacyjną z pracami Kościoła w Polsce. Każdy zakon przesyłał na zakończenie roku do sekretarza Konsulty ankietę na temat rocznej działalności zakonu w Polsce. Relacje Konsulcie składali także przedstawiciele zakonów pracujący w różnych Komisjach Episkopatu ze spraw, które odnosiły się do zakonów. Przyjmowała sprawozdania z prac komisji oraz zatwierdzała programy różnych zjazdów czy

${ }^{28}$ AKWPZM, T. Sprawy różne, Pismo Konsulty Wyższych Przełożonych Zakonów Męskich w Polsce do ks. Prałata Agostino Casaroli Podsekretarza Stanu do Spraw Nadzwyczajnych z 6 III 1967 r., b.p.

${ }^{29}$ AKWPZM, T. Sprawy różne, List przewodniczącego Konsulty zakonnej prowincjała werbistów ks. F. Zapłaty do Prymasa Polski S. Wyszyńskiego z 25 VI 1962 r., b.p. 
kursów dla zakonników. Przygotowywała zebrania plenarne, koordynowała prace Komisji, zatwierdzała ich plany oraz przydzielała zadania. Wiele razy interweniowała bezpośrednio u władz państwowych w obronie bytu i działalności zakonów np. w sprawie usuwania zakonników ze szkół. Przygotowywała treść zbiorowych listów podpisywanych następnie przez wszystkich prowincjałów np. w sprawie otwarcia NSD oraz protest przeciwko dyskryminacji z racji przynależności do zakonu $^{30}$. Opracowała też projekt umowy instytutów zakonnych z ordynariuszami w sprawie przekazania parafii zakonom. W czasie wizyty w Polsce wysłannika Stolicy Apostolskiej Podsekretarza Stanu do Spraw Nadzwyczajnych ks. prałata Agostino Casaroli w 1967 r., Konsulta Wyższych Przełożonych Zakonów Męskich przedstawiła mu pisemnie sytuację zakonów w PRL (ich stan, działalność i trudności na jakie napotykają ze strony władz państwowych) ${ }^{31}$. W drugiej połowie lat 70. wystosowała do Prymasa Memoriał w sprawie afiliacji WSD zakonnych do Papieskich Wydziałów Teologicznych w kraju, opracowała uwagi i postulaty dotyczące projektu Prawa Zakonnego i opracowała uwagi do projektu okólnika UdSW w sprawie rejestracji domów zakonnych oraz memoriał dla abp. L. Poggi (1977 r.) o życiu i działalności zakonów w Polsce ${ }^{32}$.

${ }^{30}$ AKWPZM, T. Sprawy różne, Sprawozdanie z działalności Zakonów męskich z 1959 r., b. p.; AKWPZM, t. sprawy różne, Zgłoszenia do Komisji, Warszawa dnia 15 V 1975 r., b. p.; AKWPZM, t. sprawy różne, Komisje Konferencji Wyższych Przełożonych Zakonów Męskich w 1972 r., b. p., AKWPZM, t. sprawy różne, Skład Komisji przy Konsulcie WPZM - XI 1972 r., b. p.

${ }^{31} \mathrm{~W}$ piśmie do Casarolego zakony przedstawiły trudności stawiane zakonom w Polsce, które hamowały rozwój i niejednokrotnie groziły zagładą. Zaliczali do nich: pozbawienie zakonów realizacji swojej specyficznej konstytucyjnej działalności (szkoły, szpitale), niemożność zakładania nowych domów, nowych placówek zakonnych, przez władze nie dopuszczają do obejmowania przez zakony parafii, prowincjałowie, gdy chcieli zmienić proboszcza zakonnego władze państwowe często na to się nie zgadzały, dyskryminacja zakonników przez zakaz nauczania religii, nawet we własnych kościołach, zakonnicy nauczają religii, ale wbrew prawu, za co spotykały ich kary (grzywna, areszt), władze zlikwidowały prawie wszystkie NSD, które były głównym źródłem powołań zakonnych, skarżyli się na wizytacje WSD przez wyznaniowców. Ich zdaniem źródłem konfliktów między zakonami a władzą państwową było „prawo o stowarzyszeniach”, w które komuniści próbowali wciagnaç zakony. Zakony takiego stanowiska nie przyjęły i broniły się prze podciągnięciem ich pod prawo o stowarzyszeniach. Źródłem ciagłych trudności dla zakonów był UdSW. Innym źródłem, były przepisy podatkowe dotyczące osób duchownych. Zakony płaciły podatek w wysokości 65 $\%$, kolejne trudności to traktowanie nieruchomości przejęte po wojnie po zakonach niemieckich. Początkowo nieruchomości te przejmowali zakony później odmówiono zakonom charakteru osób prawnych prawa publicznego i nakazano im płacić czynsz za użytkowanie tych nieruchomości. Zakony oparły się temu jak inne instytucje kościelne.. Zakony miały trudności w zameldowaniu swoich członków w dużych miastach. Spore trudności napotykali prowincjałowie w wyjazdach na kapituły generalne. Władze odmawiały zakonnikom pozwolenia na wyjazd na studia zagranica, duże trudności komuniści robili z wyjazdem na misje, gdzie polskie prowincje zakonne miały swoje placówki. AKWPZM, t. sprawy różne, Pismo Konsulty Wyższych Przełożonych Zakonów Męskich w Polsce do ks. Prałata Agostino Casaroli Podsekretarza Stanu do Spraw Nadzwyczajnych z 6 III 1967 r., b. p.

${ }^{32}$ AKWPZM, t. Konferencja Wyższych Przełożonych, Sprawozdanie z działalności Konferencji Wyższych Przełożonych Męskich Instytutów Zakonnych w Polsce, b. p. 
Działalność Konferencji koncentrowała się na trzech obszarach: zaznajamianie się z zarządzeniami Stolicy Apostolskiej i wprowadzanie ich w Polsce, problematyką pomocy zakonów męskich w pracy duszpasterskiej Kościoła w Polsce i poszukiwaniu wspólnych rozwiązań oraz podejmowanie wspólnie decyzji dotyczących przeszkód stawianych przez władze PRL ${ }^{33}$. Te zagadnienia były rozpatrywane także w różnych powołanych przez Konsultę komisjach oraz spotkaniach grup zakonnych, np. spotkaniach mistrzów nowicjatów, rekolekcjonistów. Konferencje plenarne od 1957 r. odbywały się 2 razy w roku w maju i październiku. Wyjątkowych potrzebach odbywały się częściej. Do stałych ich punktów należało: sprawozdanie z działalności Konsulty, komisji i sekretariatu, wysłuchanie referatów i dyskusja oraz z informacji i wyjaśniania przepisów państwowych odnoszących się życia religijnego i zakonnego. Na zebraniach plenarnych były omawiane zawsze sprawy administracyjne związane z międzyzakonnymi pracami, sprawy aktualnych stosunków Kościoła i zakonów z władzami państwowymi. Zjazdy prowincjałów były poświęcone konkretnym sprawom, np. w 1952 r. dotyczyły sprawy likwidacji NSD zakonnych. W maju 1955 r. zebranie było poświęcone konfliktowi do jakiego doszło między prowincjałami zakonów męskich a episkopatem. Prowincjałowie zarzucili biskupom prowadzenie złej polityki na odcinku zakonnym i nie podejmowanie obrony zakonów przed systematyczną ich likwidacją przez władze komunistyczne ${ }^{34}$. Sprawa dotyczyła zapowiadanego przez władze komunistyczne obowiązku składania ślubowania przez przełożonych zakonnych. Przeciwko temu wystapił opat benedyktynów z Tyńca o. Rostworowski. Poparł go prowincjał redemptorystów ks. K. Hołda, prowincjał karmelitów oraz przeor kamedułów ${ }^{35}$. Zgodę na to bp. Z. Choromański tłumaczył się wyborem mniejszego zła dla uniknięcia większego. W związku z deklaracjami nieskładania przez prowincjałów ślubowania, zagroził, nie brania na siebie za to odpowiedzialności i brakiem z jego strony pomocy w wypadku, gdyby „coś się działo z zakonem". W głosowaniu nad tą sprawą, większość prowincjałów przy-

${ }^{33} \mathrm{Na}$ konferencjach do stałych punktów należało: sprawozdanie z działalności Konsulty, komisji i sekretariatu, referaty, dyskusje oraz z informacje i wyjaśnianie przepisów państwowych odnoszących się życia religijnego i zakonnego. AKWPZM, t. Konferencje WPZM, Program Konferencji Duszpasterskiej na Jasnej Górze w dniach 11-12 XII 1951 r., b. p.; AKWPZM, T. Sprawy różne, Tematy Referatów wygłoszonych na Konferencjach Plenarnych Przełożonych Zakonów Męskich / IV1952 - IV1972/ - X1976 - V1991, b. p.; AKWPZM, T. Konsulta, Sprawozdanie z działalności Konsulty w okresie kadencji: 12 V 1969 - 10 IV 1972, b. p.; AKWPZM, T. Konferencja Wyższych Przełożonych, Sprawozdanie z działalności Konferencji Wyższych Przełożonych Zakonów Męskich w Polsce za okres 1 XI 1973 - 1 X 1974, b. p.; AKWPZM, T. Konferencja Wyższych Przełożonych, Sprawozdanie z działalności Konferencji Wyższych Przełożonych Męskich Instytutów Zakonnych w Polsce, b. p.; AKWPZM, T. Konferencja Wyższych Przełożonych, Sprawozdanie z działalności Konferencji Wyższych Przełożonych Zakonów Męskich w Polsce za okres 1 X 1972 - 1 XI 1973, b. p.

${ }^{34}$ IPN, sygn. 01283/1062, mf V14-51/52-2/5, Informacja z przebiegu zjazdu prowincjałów i wyższych przełożonych zakonnych, która odbyła się w dniu 9 V 1955 r. w Warszawie, k. 347.

${ }^{35}$ Wcześniej w tej sprawie w Tyńcu spotkał się prowincjał kapucynów i opatem O. P. Rostworowskim. IPN, sygn. 01283/1057, V14-51P -1/-3, Wyciag z doniesienia agenta ps. „Franek” z dn. 17 XI 1953 r., k. 125. 
jęła argumenty sekretarza episkopatu i opowiedziała się jednak za ewentualnym ślubowaniem ${ }^{36}$. W lutym $1957 \mathrm{r}$. celem zjazdu była sprawa określenia zadań i roli zakonów w ówczesnej sytuacji w Polsce. W tym roku. wyżsi przełożeni zakonni omawiali także sprawy relacji z władzami państwowymi oraz kwestie dotyczące wydawnictw zakonnych, zakonnych NSD, odzyskania domów zakonnych, kontaktów z naczelnymi władzami zakonnymi, współpracy zakonów z hierarchią kościelną i klerem diecezjalnym, roku maryjnego i Millenium, problematykę życia zakonnego w Instrukcji Stolicy Apostolskiej, nowicjatów, wychowania i studiów zakonnych, rządów i dyscypliny zakonnej oraz sprawę statutu ramowego ${ }^{37}$. Zagadnieniom podniesienia poziomu intelektualnego i dyscypliny zakonnej poświęcono obrady Zjazdu Wyższych Przełożonych Zakonnych w maju 1958 roku. Zajęło się również Papieskim Dziełem Powołań Zakonnych. We wrześniu 1958 r. na kolejnym zjeździe przełożonych wyższych zajęto się sprawami duszpasterstwa specjalistycznego. Na tym odcinku zakony rozwinęły ożywioną działalność, organizując dla poszczególnych grup zawodowych szczególnie inteligencji (nauczyciele, lekarze, prawnicy, pisarze) odczyty, dyskusje, rekolekcje, imprezy, zjazdy, obozy. Komuniści byli przekonani, że to duszpasterstwo służy jedynie Kościołowi w kształtowaniu aktywistów kościelnych, wpajaniu im ,ideologii katolickiej" i przeciwstawianiu jej ideologii marksistowskiej ${ }^{38}$. W $1959 \mathrm{r}$. omawiano m.in. takie sprawy jak: zapoznanie się i praktyczne wykorzystanie wskazań Stolicy Apostolskiej dotyczące życia zakonnego, ustalenie stałego programu prac Konferencji odnośnie życia zakonnego oraz omówiono możliwości odzyskania utraconych budynków szczególnie po NSD i określeniem wspólnego stanowiska i wspólnych działań wobec zmieniających się przepisów państwowych zwłaszcza odnoszących się do NSD i WSD. Na tej konferencji zajęto się także kwestią młodych kapłanów zakonnych, formacją duchową kleryków w WSD oraz problematyką braci zakonnych (dokształcaniem ich $\mathrm{w}$ dziedzinie religijnej i zawodowej). Na prośbę biskupów Zajęła się również zagadnieniem pełniejszego włączenia zakonów w duszpasterstwo w związku z potrzebami Kościoła w Polsce i wskazaniami episkopatu. W latach 60 . Konsulta i konferencje prowincjałów zajęły się szczególnie kwestią braci zakonnych, gdyż stawał się to poważany problem życia zakonnego w Polsce. W 1962 r. zajmowano się przede wszystkim sprawami soborowymi, pracą duszpasterską zakonów i jej wpływem na karność zakonną. Sprawa ta była szczególnie drażliwa dla zakonów z powodu podejmowania licznych parafii w wyniku likwidacji własnych dzieł zakonnych. W 1963 r. Konferencje prowincjałów zajęły się zmianami w statucie Konferencji oraz problemowi ,accommodata renovatio" życia zakonnego w polskich warunkach oraz jak co roku

${ }^{36}$ Tamże, k. 348.

${ }^{37}$ KWPZM. AKWPZM, T. Konferencje WPZM, Posiedzenie WPZM, Warszawa dnia 13 II 1957 r., b. p.

${ }^{38}$ IPN, sygn. 01283/1062, Informacja. Działalność zakonów po październiku 1956 r., Warszawa 1959, k. 20-21; AKWPZM, t. sprawy różne, Sprawozdanie z działalności Zakonów męskich z 1963 r., b. p.; W 1963 r. na konferencji wysunięto projekt utworzenia Instytutu higieny psychicznej dla kapłanów oraz zastanawiano się jak pomóc tym którzy porzucili kapłaństwo i chcieli powrócić. Zob. AKWPZM, T. Sprawy różne, Sprawozdanie z działalności Zakonów męskich z 1964 r., b. p. 
w czasie wielkiej nowenny planem duszpasterskim wielkiej nowenny. Obok tych zagadnień poruszono również zagadnienie życia zakonnego jako źródła wzmożonego duszpasterstwa parafialnego, udział zakonów w duszpasterstwie zwyczajnym oraz sprawę wikariusza zakonnego na parafii niezakonnej oraz psychologicznymi i sytuacyjnymi warunkami życia zakonnego w Polsce. W kwietniu 1964 r. omawiano sprawę postawy zakonnika wobec kultury współczesnej, wobec rozrywek kulturalnych, umysłowych i artystycznych oraz przyczyny kryzysów i załamań zakonników i środki zaradcze w świetle instrukcji z 1961 r. W 1964 r. obecny na zebraniu Prymas zwrócił się do zakonów o przeciwstawienie się powstającym stowarzyszeniom ateistycznym przez uaktywnienie pracy z młodzieżą i organizowanie wydawnictw katolickich. Zalecił również reaktywowanie NSD zakonnych i upominanie się o zwrot domów nowicjackich i innych. Polecił także by zdolniejszych zakonników przełożenie wysyłali na specjalistyczne studia do Rzymu. Na tym zjeździe prowincjałów podjęto także na nowo sprawę współpracy zakonów z biskupami w dziełach apostolskich w diecezji. W czasie Soboru Watykańskiego II i w pierwszych latach po soborze cały wysiłek pracy Konsulty koncentrował się na realizacji dekretów soborowych i odnowie życia zakonnego według niego. Omawiano dokumenty soborowe i wskazania soboru odnoście odnowy życia zakonnego w ramach odnowy Kościoła. Zajęto się także sprawą kierunków zmian odnoście prawa zakonnego ${ }^{39}$. W październiku 1967 r. (25-26) konferencja z udziałem Prymasa S. Wyszyńskiego oraz bp. B. Dąbrowskiego dotyczyła uchwał soborowych oraz dekretów soborowych dotyczących zakonów. Prowincjałowie też złożyli sprawozdania z udziału w kapitułach generalnych. W zawiązku z groźbą zamknięcia w 1967 r. niektórych WSD zakonnych Konsulta na swoim posiedzeniu 4 I 1967 r. postulowała by biskupi szukali modus vivendi i zmienili wydane zarządzenia w sprawie WSD. Konsulta była zdania, że ,upór do niczego nie prowadzi, ponieważ władze mogą drogą stosowania środków administracyjnych przymusić administrację kościelną do poszanowania przepisów $\mathrm{w}$ dziedzinie oświaty i stowarzyszeniach ${ }^{40}$. Dlatego w tej sprawie wystosowali pisma do Sekretariatu Episkopatu by złagodził zarządzenia w tej kwestii. Konsulta była bardziej skłonna do wszelkich kompromisów z władzą komunistyczną niż Episkopat. Prowincjałowie doszli do wniosku, że upór do niczego nie doprowadzi a władze mogą zastosować administracyjne środki i zmusić stronę kościelną do respektowania przepisów w dziedzinie oświaty ${ }^{41}$. W latach $1964-1968$ dyskutowanonad postawązakonników wobec kultury współczesnej. Omówiono teżwświetle instrukcji z 1961 r. przyczyny kryzysów i załamań zakonników oraz środki zaradcze. Konferencja ustaliła jedną linię postępowania zakonników w kwestii prób wizytacji władz państwowych w WSD i punktach katechetycznych ${ }^{42}$. W 1970 r. głównym tematem Konferencji było znaczenie nowej liturgii dla życia zakonne-

${ }^{39}$ IPN, sygn. 0445/118 Informacja nr 3/V dotycząca kleru 6 III 1957, k. 23.

${ }^{40}$ AAN, UdSW, sygn. 133/121, Notatka służbowa ze spotkania w Wydziale Wyznań PWRN w Krakowie z ks. Andrzejem Wróblem prowincjałem pijarów z 16 II 1967 r., k. 80.

${ }^{41}$ AAN, UdSW, sygn. 133/121, k. 80.

${ }^{42}$ AKWPZM, T. Konferencja Wyższych Przełożonych, Konferencja Wyższych Przełożonych Zakonów Męskich w Polsce (1964-1968), b.p. 
go i przeprowadziła ankietę we wszystkich WSD zakonnych na temat organizacji studiów w tych seminariach. Na październikowym zebraniu 1971 r. omawiano kwestię procedur nabywania dóbr kościelnych na Ziemiach Zachodnich i Północnych $^{43}$. W czasie plenarnego zebrania w maju 1974 r. zajęto się kwestią pracy duszpasterskiej zakonników w parafiach i niebezpieczeństwem zacierania się różnicy miedzy klerem zakonnym a diecezjalnym, co odbija się negatywnie na życiu zakonnym. Zwrócono uwagę żeby nie przyjmować i tworzyć małych placówek, gdyż one uniemożliwiaja, utrudniają życie wspólnotowe zakonników ${ }^{44}$. W 1978 r. obrady Konferencji były skupione wokół zagadnienia ubóstwa zakonnego, gdyż jak stwierdzono, „Okazałe domy, sposób życia, mieszkania czy podróżowania zakonników nie zawsze daje dobre świadectwo ubóstwa, do którego zakonnicy zobowiązują się specjalnym ślubem" ${ }^{45}$. W czasie Konferencji Prowincjałów od kwietnia 1952 do 1991 r. wygłoszono174 różnego rodzaju konferencje z dziedziny teologii życia zakonnego, prawa zakonnego, pastoralnej, duszpasterskiej, formacyjnej, psychologii, kultury, dokumenty Stolicy Apostolskiej. Tematykę konferencji starano się dopasować do aktualnych problemów życia zakonnego i Kościoła w Polsce np. w X 1956 - tematem konferencji było - Aktualne Problemy życiazakonnego, w 1957r.-temat-Apostolsko duszpasterskiewykształcenieiprzygotowanie kapłanów zakonnych, w 1960 r. - Zagadnienie kryzysu powołań braci zakonnych, w 1964 r. - Postawa zakonnika wobec kultury współczesnej, w 1975 r. - Tendencje odnowy życia zakonnego itp. ${ }^{46}$ Konferencja aż do 1980 r. nie posiadała własnego biuletynu informacyjnego, gdyż nie mogła uzyskać na to pozwolenie władz państwowych na jego wydawanie. Prymas S. Wyszyński starał się zawsze uczestniczyć w zjazdach prowincjałów i informować wyższych przełożonych zakonnych o aktualnych sprawach Kościoła w Polsce i relacjach Kościół Państwo oraz apelował do zakonów w różnych sprawach, np. w 1962 r. zaapelował do Konsulty o podjęcie kwestii dotyczącej międzyzakonnej pracy dla dobra Kościoła w Polsce ${ }^{47}$. Oprócz niego w tych spotkaniach uczestniczył Sekretarz episkopatu. W zjazdach prowincjałów uczestniczyli także inny biskupi. W 1951 r. na

${ }^{43}$ Przy sporządzeniu aktów prawnych miały być obecni przedstawiciel zakonu, przedstawiciel kurii diecezjalnej i władz państwowych. Episkopat zarządził by najpierw odbyło się zebranie przedstawiciela zakonu i Kurii diecezjalnej by wobec władz państwowych działać w sposób uzgodniony. Zakony nie obawiały się o własność niemieckich swoich współbraci. Trudniejsza była sprawa z nieruchomościami przejętymi po wojnie, gdzie byli tylko użytkownikami, a nigdy diecezja. Na tym tle dochodziło do konfliktów z biskupami z tych terenów. IPN, sygn. 0639/55, t. 3, Notatka służbowa z odbytego doraźnie spotkania z tw. „Majewski” dn. 17 IV 1971 r. w godz. 18.00 -20.00, k. 110; tamże, Doniesienie. Zebranie Konsulty zakonnej Niepokalanów 5-6 X 1971 r. Źródło „Majewski”, k. 197.

${ }^{44}$ AKWPZM, T. Konferencja Wyższych Przełożonych, Sprawozdanie z działalności Konferencji Wyższych Przełożonych Zakonów Męskich w Polsce za okres 1 XI 1973 - 1 X 1974, b.p.

${ }^{45}$ AKWPZM, T. Konferencja Wyższych Przełożonych, Sprawozdanie z działalności Konferencji Wyższych Przełożonych Męskich Instytutów Zakonnych w Polsce, b.p.

${ }^{46}$ AKWPZM, T. sprawy różne, Tematy Referatów wygłoszonych na Konferencjach Plenarnych Przełożonych Zakonów Męskich /IV1952-IV1972/ - X1976 - V1991, b.p.

${ }^{47}$ AAN, UdSW, sygn. 133/121, Notatka służbowa z 2 XI 1967 r., k. 103. 
grudniowej konferencji uczestniczył bp. Kowalski z Pelplina. ${ }^{48} 18$ XII 1967 r. w zjeździe prowincjałów uczestniczył metropolita krakowski K. Wojtyła i apelował do prowincjałów, aby oddelegowali kapłanów zakonnych do pracy duszpasterskiej w diecezji. Książa zakonni są jego zdaniem potrzebni szczególnie w pracy z młodzieżą i wiernymi w parafii w czasie rekolekcji i misji parafialnych. To zaangażowanie argumentował - „Obecne czasy [...] kreślące laicyzację, ateizm wymagają aktywności w krzewieniu prawdy Bożej. Ona bez osłonek winna dotrzeć do każdego serca młodzieży, starszych, by ich umocnić w odporności przed współczesną laicyzacją, indyferentyzmem" ${ }^{49}$. W maju 1976 r. przedstawił prowincjałom kwestię umów o współpracę naukową WSD z istniejącymi w kraju Papieskimi Wydziałami Teologicznymi ${ }^{50}$. W wiele czasu na Konferencjach poświęcono kwestii współpracy zakonników z duchowieństwem diecezjalnym i podawano najnowsze zarządzenia Stolicy Apostolskiej dotyczące zakonów ${ }^{51}$.

Zjazdami prowincjałów i Konsultą interesowały się komunistyczne władze w Polsce. W latach stalinowskich nie będąc zorientowani, co do celów i zadań mimo działań operacyjnych bezpieki władze uznały je za niebezpieczne. Komuniści sądzili, że jednym z głównych zadań prezydium prowincjałów było zbieranie, poprzez poufnych informatorów, wiadomości stanowiących tajemnice państwową z dziedziny administracji, bezpieczeństwa, szkolnictwa, sądownictwa, partii politycznych, itp. ${ }^{52}$. Taką tezę bezpieka chciała udowodnić w czasie przesłuchań ks. E. Bulandy i ks. Stanisława Forysa na przełomie 1949/1950 ${ }^{53}$. Posiedzenia Konsulty były dla nich analogią do posiedzeń episkopatu. Władze komunistyczne nie przejmowały do wiadomości istnienia i działania Konsulty Wyższych Przełożonych, ponieważ Konsulta nie dopełniła obowiązku uregulowania swojego bytu prawnego we właściwym urzędzie państwowym, jakie nakładało według ich opinii rozporządzenie Ministra Administracji Publicznej z 6 VIII 1949 roku. W związku z tym, w grudniu 1960 r. odmówiły wydania zgody na wyrobienie pieczątki na potrzeby Konsulty zakonnej ${ }^{54}$. Zdaniem komunistów Konferencja Wyższych Przełożonych powstała „w celu sprawniejszego i korzystniejszego wyeksploatowania ich fanatyzmu i oddania się Kościołowi w Polsce" oraz usystematyzowania i skoordynowania działalności zakonów w planowanych przez episko-

${ }^{48}$ AKWPZM, T. Konferencje WPZM, Program Konferencji Duszpasterskiej na Jasnej Górze w dniach 11-12 XII 1951 r., b.p.

${ }^{49}$ AAN, UdSW, sygn. 133/121, Notatka służbowa ze spotkania w Wydziale Wyznań PWRN w Krakowie z ks. Andrzejem Wróblem prowincjałem pijarów z 6 I 1968 r., k. 111.

${ }^{50}$ AKWPZM, T Konferencja Wyższych Przełożonych, Sprawozdanie z działalności Konferencji Wyższych Przełożonych Męskich Instytutów Zakonnych w Polsce, b.p.

${ }^{51}$ AKWPZM, T. Konferencja Wyższych Przełożonych, Sprawozdanie z działalności Konferencji Wyższych Przełożonych Męskich Instytutów Zakonnych w Polsce, b.p.

${ }^{52}$ IPN, sygn. 01283/1057, V14-51P -1/-1, Protokół z przesłuchania podejrzanego, Bydgoszcz 5 XII 1949 r., k. 27.

${ }^{53}$ Tamże.

${ }^{54}$ AAN, UdSW, sygn. 133/15, Poufne pismo Naczelnika Wydziału UdSW Aleksandra Wołowicza do Dyrektora Gabinetu Prezesa GUKPPiW E. Kozikowskiego z 16 I 1970 r., k. 334. 
pat „kierunkach uderzeniowych” przeciwko państwu ludowemu ${ }^{55}$. Konsultę zakonną władze państwowe traktowały jako instytucję niemającą żadnych uprawnień do reprezentowania zakonów na zewnątrz a jej dyrektywy wysyłane do poszczególnych zakonów odnośnie stosunków z władzami państwowymi starały się dezawuować. Dla władz jedyną stroną był zakon reprezentowany przez prawne osoby $^{56}$. Konferencjami prowincjałów i ich tematyką $z$ racji swoich zadań szczególnie interesował się Urząd do Spraw Wyznań (UdsW). otrzymywał informacje dotyczące działań Konsulty Wyższych Przełożonych czasami z bezpośredniego źródła. Informacje przekazywali mu członkowie a nawet przewodniczący Konsulty. Wiele informacji na temat jej pracy, planów i działań przekazał prowincjał pijarów ks. Andrzej Wróbel ${ }^{57}$. W 16 II 1967 r. przybył do Wydziału Wyznań PWRN w Krakowie, jak obiecał wydziałowi wyznań w czasie rozmowy 7 lutego tego roku, i złożył krótką relację z posiedzenia Konsulty zakonnej odbytej w Warszawie 10 II 1967 r., omawianych tam tematów (planów, zamierzeń i podejmowanych działań $)^{58}$. Podobne informacje o pracy Konsulty przekazał Wydziałowi Wyznań PWRN w Krakowie także w styczniu 1968 roku $^{59}$. UdSW interesowały również konferencje krajowe duszpasterzy np. duszpasterstwa stanowego, zawodowego i specjalistycznego z grudnia $1967 \mathrm{r}$. (kto prowadził i kto uczestniczył oraz kto uczestniczył w konferencji Komisji Duszpasterskiej Episkopatu $)^{60}$. W połowie lat 70. zdaniem władz wyznaniowych Konsulta ówczesna wypowiadała się za ściślejszymi powiązaniami z Episkopatem i za ograniczeniem kontaktów z władzami państwowymi (ks. Bartoszewski, Podgórski, Koczwara, Mroczkowski, Szymanek) ${ }^{61}$. Kosulta zakonna starała się wystrzegać działań, które mogłyby skłócić zakony z władzami państwowymi. UdSW starał się utrzymywać zwłaszcza w latach 70 i 80. poprawne stosunki z Konsultą Wyższych Przełożonych Zakonnych w Polsce. Dlatego zdarzało się, że UdSW podważał nieprzychylne decyzje wojewodów dla zakonów dotyczących zakładania nowych domów zakonnych, których prowincjałowie byli członkami Konsulty, np. w sierpniu 1980 r. domagał się od wojewody nowosądeckiego zalegalizowania budowanego przez redemptorystów domu rekolekcyjno-wypoczynkowego w Kościelisku - Sobiczkowej, ponieważ ks. Stanisław Podgórski był w tym czasie przewodniczącym Konsulty

\footnotetext{
${ }^{55}$ AAN, UdSW, sygn. 133/13, Notatka informacyjna dot. działalności zakonów w Polsce, k. 1.

${ }^{56}$ AAN, UdSW. Sygn. 142/1, Analiza konstytucji zakonnych w świetle artykułu 19 prawa o stowarzyszeniach, k. 26.

${ }^{57}$ AAN, UdSW, sygn. 133/121, Notatka służbowa ze spotkania w Wydziale Wyznań PWRN w Krakowie z ks. Andrzejem Wróblem prowincjałem pijarów z 16 II 1967 r., k. 83; AAN, UdSW, sygn. 133/121, Notatka służbowa ze spotkania w Wydziale Wyznań PWRN w Krakowie z ks. Andrzejem Wróblem prowincjałem pijarów z 6 I 1968 r., k. 110; AAN, UdSW, sygn. 133/121, k. 80.

${ }^{58}$ AAN, UdSW, sygn. 133/121, Notatka służbowa ze spotkania w Wydziale Wyznań PWRN w Krakowie z ks. Andrzejem Wróblem prowincjałem pijarów z 16 II 1967 r., k. 83.

${ }^{59}$ AAN, UdSW, sygn. 133/121, Notatka służbowa ze spotkania w Wydziale Wyznań PWRN w Krakowie z ks. Andrzejem Wróblem prowincjałem pijarów z 6 I 1968 r., k. 110.

${ }^{60}$ AAN, UdSW, sygn. 133/121, Notatka służbowa, k. 110.

${ }^{61}$ AAN, UdSW, sygn. 133/15, E. Sztekker, Informacja o działalności zakonów i zgromadzeń zakonnych z 9 III 1976 r., k. 168.
} 
Wyższych Przełożonych Zakonnych a UdsW chciał utrzymywać z tą instytucją dobre stosunki ${ }^{62}$.

Konferencje Wyższych Przełożonych Zakonów Męskich i Konsulta zakonna były również w stałym zainteresowaniu UB a później SB. Bezpieka starała się również wszelkimi sposobami zdobyć informacje na ich temat ${ }^{63}$. Już w grudniu 1948 r., podjęła przeciwko nim śledztwo. Rok później przesłuchiwano (w grudniu 1949 r.) ks. Forysia, ks. Wojciecha Zmarza, prowincjała kapucynów Remigiusza Kranza, oraz prowincjała jezuitów ks. Bulandę ${ }^{64}$. Bezpieka chciała poznać powód i czas jej założenia, z czyjej inicjatywy, kto wchodził w skład komisji prowincjałów, jakie funkcje w niej pełnili poszczególni prowincjałowie. Interesował ich zakres i kierunek pracy (zwłaszcza działalność konferencji pod wydaniu dekretu z sierpnia 1949 r.), gdzie odbywały się spotkania, kto im przewodził, co było tematem obrad, jakie podejmowano uchwały i wytyczne, jak w praktyce były one realizowane. Ponadto interesowało ich, który z biskupów sprawował patronował konferencji, jakie wytyczne episkopat przekazywał prowincjałom w ramach konferencji ${ }^{65}$. Od oskarżonych bezpieka domagała się w czasie śledztwa opisania wszystkich posiedzeń konferencji i kto brał nich udział. Starano się dowieść ukrytej w jej ramach działalności szpiegowskiej, że na tych spotkaniach polecano prowincjałom zbieranie wszelkiego rodzaju informacje nie tylko o działalności zakonów, ale przede wszystkim o sytuacji politycznej i gospodarczej kraju, zdobywanie tajnych okólników, informacji stanowiących tajemnicę państwową, wydawanych przez władze państwowe zwłaszcza odnoszące się do zakonów ${ }^{66}$. W terenie funkcjonariuszom bezpieczeństwa nakazali przesłuchać przełożonych wyższych innych zakonów i zgromadzeń jak wygląda realizacja postanowień Konferencji w praktyce. W związku z tym, że prowincjał jezuitów ks. E. Bulanda, powołując się na przysięgę zachowania tajemnicy odnośnie treści konferencji zjazdów prowincjałów odmawiał składania jakichkolwiek zeznań w sprawie zjazdów prowincjałów, bezpieka podjęła decyzję przesłuchania i aresztowaniu przewodniczącego

${ }^{62}$ AAN, UdSW, sygn. 133/123, Pismo UdSW do Wojewody Nowosądeckiego tow. Lecha Bafia z 19 VIII 1980 r., k. 29.

${ }^{63}$ IPN BU sygn. 0445/118 Informacja nr 3/V dotycząca kleru 6 III 1957, k. 22.

${ }^{64}$ IPN, sygn. 01283/1057, V14-51P -1/-2, Uzupełnienie do planu śledztwa w sprawie przeciwko Zmarzowi Wojciechowi, k. 34.; IPN, sygn. 01283/1057, V14-51P -1/-2, Raport z przesłuchania i rozmowy z prowincjałem Kapucynów Kranz Remigiuszem z dnia 19 XII 1951 r., k. 36; Protokół z przesłuchania podejrzanego, Kraków 12 XII 1951 r., k. 40-41; IPN, sygn. 01283/1057, V14-51P -1/-2, Protokół z przesłuchania podejrzanego, Kraków 13 XII 1951 r., k. 42-45; tamże, Protokół z przesłuchania podejrzanego, Kraków 14 XII 1951 r., k. 46-50; IPN, sygn. 01283/1057, V14-51P $-1 /-2$, Streszczanie sprawy przeciwko Bulandzie Edwardowi, prowincjałowi zak. Jezuitów i tow. tow., k. 52-56.

${ }^{65}$ IPN, sygn. 01283/1057, V14-51P -1/-2, Uzupełnienie do planu śledztwa w sprawie przeciwko Zmarzowi Wojciechowi, k. 34-35; IPN, sygn. 01283/1057, V14-51P -1/-2, Streszczanie sprawy przeciwko Bulandzie Edwardowi, prowincjałowi zak. Jezuitów i tow. tow., k. 52-56.

${ }^{66}$ IPN, sygn. 01283/1057, V14-51P -1/-2, Streszczanie sprawy przeciwko Bulandzie Edwardowi, prowincjałowi zak. Jezuitów i tow. tow., k. 52-56. 
Komisji prowincjała bernardynów O. B. Szepelaka ${ }^{67}$. Po intensywnym, okrutnym śledztwie ks. E. Bulanda załamał się i zaczął składać zeznania na temat spotkań prowincjałów ${ }^{68}$. Po wydaniu przez komunistyczne władze dekretu o obsadzaniu duchownych stanowisk kościelnych, w kwietniu 1953 r. UB wznowił zainteresowanie konsultą zakonną. W tej sprawie został przesłuchany w więzieniu jako podejrzany Cezary Hański. Domagano się od niego dokładnych informacji o zebraniach prowincjałów ich tematyce, postanowieniach i wnioskach. Dzięki czemu, bezpieka zdobyła kolejne informacje o tej inicjatywie prowincjałów i jej począt$\operatorname{kach}^{69}$.

Konferencje Wyższych Przełożonych Zakonów Męskich w Polsce były pod stałą obserwacją agentury z różnych zakonów, która zbierała wszelkie informacje na ich temat: kto uczestniczył z biskupów, jakie były poruszane sprawy, jakie podejmowano decyzje itp. ${ }^{70}$. Dzięki czemu miała informacje na bieżąco z kilku niezależnych źródeł agentury. Relację o przebiegu zjazdu prowincjałów z 28 XII 1952 r. w Częstochowie przekazał m.in. inf. ps. „Lisowski”, inf. ps. „Ostrożny” oraz inf. ps. Antena" "71. O zebraniu prowincjałów pod przewodnictwem bpa Z. Choromańskiego u dominikanów w Krakowie z 12 listopada 1953 r. (to spotkanie prowincjałów było poświęcone deklaracji Episkopatu po uwięzieniu Prymasa Wyszyńskiego), informacje bezpiece przekazał inf. ps. „K”, inf. ps. „Eliasz”73, inf. ps. „Franek"74 i inf. ps.,,Gryf"75. Na temat Konsulty w 1971 r. jak i w innych latach donosił bezpiece oblat TW „Majewski”, który te wiadomości czerpał bezpośrednio w rozmowach z prowincjałem oblatów ks. Tomysem ${ }^{76}$. O kwietniowej konferencji z 1983 r., która dotyczyła przygotowań do mającej się odbyć w tym roku pielgrzymki papieskiej w Polsce, informacje przekazał TW „Adam” ze zgro-

${ }^{67}$ IPN, sygn. 01283/1057, V14-51P -1/-2, Streszczanie sprawy przeciwko Bulandzie Edwardowi, prowincjałowi zak. Jezuitów i tow. tow., k. 56; IPN, sygn. 01283/1057, V14-51P -1/-1, Oświadczenie w sprawie kwestii konferencji prowincjałów, k. 1.

${ }^{68}$ IPN, sygn. 01283/1057, V14-51P -1/-1, Zeznanie Edwarda Bulandy w sprawie organizacji i działalności Konferencji Prowincjałów Zakonnych i Prezydium z Sekretariatem, k. 2.

${ }^{69} \mathrm{Z}$ nim konsultowano wszystkie sprawy dotyczące także relacji zakonów $\mathrm{z}$ władzami państwowymi. IPN, sygn. 01283/1157, Protokół. Przesłuchania podejrzanego z dnia 27 IV 1953, k. 153-156.

${ }^{70}$ IPN, sygn. 0416/1074, Informacja za zjazdu wyższych przełożonych zakonnych, który obył się w dniach 16 i 17 V 62 w Lądzie pow. Słupca, Warszawa 30 VI 1962 r., k. 98-100.

${ }^{71}$ IPN, sygn. 01283/1057, V14-51P -1/-3, Informacja ustna, Bydgoszcz 9 I 1953 r., k. 103.; tamże doniesienie informacyjne z 13 I 1953 r., k. 106.

${ }^{72}$ IPN, sygn. 01283/1057, V14-51P -1/-3, Doniesienie Informacyjne, Kraków 13 XI 1953 r., k. 121.

${ }^{73}$ IPN, sygn. 01283/1157, Doniesienie z dnia 14 XI 1953 r., k. 167.

${ }^{74}$ IPN, sygn. 01283/1057, V14-51P -1/-3, Wyciąg z doniesienia agenta ps. „Franek” z dn. 17 XI 1953 r., k. 125.

${ }^{75}$ IPN, sygn. 01283/1157, Doniesienie agenturalne z dnia 14 XI 1953 r., k. 174-176.

${ }^{76}$ IPN, sygn. 0639/55, t.3, Notatka służbowa z odbytego doraźnie spotkania z tw. „Majewski” dn. 17 IV 1971 r. w godz. 18.oo -20.oo, k. 110-111. 
madzenia salezjanów ${ }^{77}$. W 1974-1975 do inwigilacji posiedzeń Konferencji Wyższych Przełożonych Zakonnych oprócz techniki operacyjnej wykorzystywano tajnych współpracowników ps. „Pawel”. ${ }^{78}$ W latach 1978-1979 . Konferencje prowincjałow obstawiali TW: „Stanisławski”, „Zabytek”, „,Konsul”, „Stefan”, „Henryk”, „Stanisław”. ${ }^{79}$ Informacje z posiedzeń Komisji Duszpasterstwa Akademickiego wykorzystywano TW „Przemysław”. Konferencje Wyższych Przełożonych Zakonów Męskich.

${ }^{77}$ IPN, sygn. 01283/1179, Wyciąg z notatki służbowej dot. spotkania z tw. ps. „Adam” z 6 V 1983 r., k. 75.

${ }^{78}$ Informacja na temat głównych zadań i planów pracy Wydziału V Departamentu IVMSW na lata 1974-1975, w: Plan pracy Departamentu IV MSW na lata 1972-1979, opr. M. Biełaszko, A. K. Piekarska, P. Tomasik, C. Wilanowski, Warszawa 2007, s. 121.

${ }^{79}$ Informacja na temat planów pracy Wydziału V Departamentu IV MSW na lata 1978-1979, w: Plany pracy Departamentu IV MSW na lata 1972-1979, opr. M. Biełaszko, A.K. Piekarska, P. Tomasik, C. Wilanowski, Warszawa 2007, s. 296-297. 